ADI WIDYA: Jurnal Pendidikan Dasar FAKULTAS DHARMA ACARYA UNIVERSITAS HINDU NEGERI I GUSTI BAGUS SUGRIWADENPASAR
Volume. 6, Nomor 1 April 2021

ISSN: $2685-8312$ (online)

ISSN: 2527-5445 (cetak

http://ejournal.ihdn.ac.id/index.php/AW

\title{
ANALISIS PEMECAHAN MASALAH MATEMATIKA DITINJAU DARI TIPE KEPRIBADIAN PESERTA DIDIK KELAS V SEKOLAH DASAR
}

\author{
Oleh \\ Mar'atus Sholeha, Teguh Yunianto, Jannah Ulfah \\ ${ }^{1}$ UIN Raden Intan Lampung, ${ }^{1,2}$ UIN Sunan Kalijaga Yogyakarta \\ sholehamaratus03@gmail.com, teguhyunianto96@gmail.com, janahulfa9@gmail.com
}

Diterima 6 Pebruari 2021, direvisi 28 Pebruari 2021, diterbitkan 1 April 2021

\begin{abstract}
Abstrak
Tujuan penelitian ini adalah untuk mengetahui pemecahan masalah matematika ditinjau dari tipe kepribadian Hippocrates Galenus di SDN 01 Trimodadi Lampung Utara. Tahap yang digunakan dalam Analisis pemecahan masalah matematika ditinjau dari tipe kepribadian menurut Polya. Penelitian menggunakan tekhnik purposive sampling dalam pengambilan data. Hasil penelitian menunjukkan; (1) proses pemecahan masalah tipe kepribadian Kolerik sudah mampu melewati keempat tahap dengan baik namun kurang sempurna pada tahap pemeriksaan kembali jawaban akhir. (2) Proses pemecahan masalah tipe kepribadian Melankolik sudah dapat melalui keempat tahap akan tetapi masih ada kesalahan pada tahap melaksanakan rencana dalam hal perhitungan.(3) Proses pemecahan masalah tipe kepribadian Sanguinis terbilang kurang mamapu memenuhi keempat tahap proses pemecahan masalah.(4) Proses pemecahan masalah tipe kepribadian Plegmatis mampu melaksanakan keempat tahap proses pemecahan masalah dengan baik akan tetapi masih ada kesalahan dalam tahap melakukan rencana dalam hal perhitungan.
\end{abstract}

Kata Kunci: pemecahan masalah, matematika, tipe kepribadian

\section{Abstract}

Abstract is The purpose of this study was to determine the solving of mathematical problems in terms of the personality type of Hippocrates Galenus SDN 01 Trimodadi North Lampung. The stage used in the analysis of mathematical problem-solving in terms of the personality type according to Polya. The study used the purposive sampling technique in data collection. The results showed; (1) the process of solving the problem of the choleric personality type has been able to pass through the four stages well but is not perfect at the final answer re-examination stage. (2) The process of solving the problem of the melancholic personality type has gone through all four stages, but there are still errors at the stage of implementing the plan in terms of calculations. (3) The process of solving the problem of the sanguine personality type is somewhat insufficient to fulfill the four stages of the problem-solving process. problem-solving phlegmatic personality type can carry out the four stages of the problemsolving process properly, but there are still errors in the planning stage in terms of calculations. Keywords: problem solving, mathematics, personality type 


\section{PENDAHULUAN}

Pemecahan masalah dalam matematika merupakan proses dimana seorang peserta didik menerima tantangan berupa persoalan matematika yang pemecahan masalahnya memerlukan ide matematika (Dewi, 2013). Pemecahan masalah merupakan bagian dari kurikulum yang sangat penting karena dalam proses pembelajaran maupun pada saat proses pemecahan masalah, peserta didik memperoleh pengalaman menggunakan pengetahuan dan keterampilan yang sudah dimiliki untuk kemudian diterapkan dalam pemecahan masalah (Hasanah, 2009).

Matematika merupakan mata pelajaran dasar, ditingkat sekolah dasar ataupun sekolah menengah, matematika berasal dari kata latin mathematika yang mulanya diambil dari bahasa Yunani mathematike yang berarti mmepelajari, kata tersebut mempunyai asal katanya mathema yang berarti pengetahuan atau ilmu (Yunianto et al., 2019). matematika ini merupakan mata pelajaran yang membutuhkan pola fikir yang logis, kritis. yang mana peserta didik diharapkan mampu berfikir secara logis dalam memecahkan permasalahan yang ada di matematika (Negara, 2016). Kemampuan pemecahan masalah itu sendiri merupakan kompetensi inti dalam kurikulum matematika yang harus dimiliki peserta didik. Melalui pemecahan masalah, aspek-aspek yang penting dalam pembelajaran matematika dapat dikembangkan dengan baik (Amalia et al., 2018).

Beberapa alasan peserta didik kurang memahami ataupun kurang menyukai mata pelajaran matematika diantaranya dapat dikatakan serperti perbedaan kepribadian dari setiap peserta didiknya (Martinah, 2018), karena tidak menutup kemungkinan dalam satu kelas peserta didik memiliki kepribadian yang berbeda-beda, oleh sebab itu dari perbedaan kepribadian itu dapat menimbulkan perbedaan antara minat belajar dari masing-masing peserta didik (Ulfah et al., 2020). Setiap individu memang tidak ada yang sama. Perbedaan individu pulalah yang menyebabkan perbedaan tingkah laku belajar dikalangan anak didik (Ahmadi et al., 2013).

Pendidik seharusnya mengenal macam-macam kepribadian peserta didiknya, serta mengetahui bagaimana cara menyikapi dari perbedaan kepribadian peserta didiknya (Saputri, 2018; Yunianto et al., 2021). Karena hal tersebut merupakan suatu factor pendukung kualitas pendidikan, selain dari pada itu akan memudahkan guru dalam menemukan potensi yang dimiliki peserta didiknya (Yunianto, 2021). Karena dalam satu kelas tidak menutup kemungkinan terdapat berbagai ragam kepribadian yang tidak mudah untuk disama ratakan pola pembelajarannya (Sjarkawi, 2013). Karena dalam setiap kepribadian memiliki cara tersendiri dalam memecahkan permasalahan yang dihadapinya, sehingga demikianlah pentingnya seorang guru memahami perbedaan kepribadian peserta didiknya (Mawaddah, 2015). kepribadian terdiri atas pola fikir, perasaan dan tingkah laku, kemampuan dan potensi dimiliki seseorang. Selain dari pada itu kebribadian satu dengan yang lainnya belum tentu sama (Sari et al., 2016). Dari perbedaan itu dapat dikatakan bahwa setiap orang mempunyai tingkahlaku yang beraneka ragam, jadi dapat dikatakan bahwa setiap orang mempunyai cara pikir yang beraneka ragam (Widjajanti, 2009). berdasarkan pada realita yang ada bahwa tingkah laku seseorang bervariasi. Psikologi merupakan ilmu yang mempelajari tentang perilaku dan jiwa manusia, baik perilaku peserta didik maupun orang lain (Anwar, 2017). 
Kepribadian merupakan system psikofisik yang bersifat dinamis dan berpengaruh terhadap cara khas seseorang dalam menyesuaikan diri terhadap lingkungannya (Barnawi et al., 2017).

Berdasarkan hasil observasi yang penulis lakukan dengan cara wawancara di SDN 01 Trimodadi, Kecamatan Abung Selatan Kabupaten Lampung Utara. Ditemukan bahwa pada sekolah tersebut peserta didiknya memiliki kepribadian yang beraneka ragam, dan pada saat obeservasi tersebut penulis berkesempatan untuk dapat mewawancarai wali kelas $\mathrm{V}$ bahwasannya beliau menyampaikan hal terkait peserta didiknya tersebut yakni cara belajar yang berbeda-beda, kepribadiannya, sehingga terkadang beliau sendiri ini merasa kesulitan dalam proses pembelajarannya . Jika dilihat dari hasil ulangan harian nilai nya masih dalam taraf standar, hanya beberapa peserta didik yang mampu melebihi nilai standar. Hal ini yang membuat peneliti tertarik untuk mendalami penelitian ditempat tersebut peserta didiknya ini sangat antusias jika dalam proses pembelajara ini diselangi dengan latihan dan kemudian ada pemberian reward berupa nilai lebih yang akan didapatnya. Dan untuk mengatasi nya permasalahan tersebut maka diperlukan metode yang tepat dalam menyikapi permasalahan yang ada, yakni dengan cara metode kompetisi.

\section{METODE}

Ditinjau dari jenis datanya penelitian ini menggunakan pendekatan kualitatif. Menurut Creswell penelitian kualitatif yakni sebuah proses penyelidikan untuk memahami masalah sosial berdasarkan pencapaian holistic yang dibentuk dengan, melaporkan pandangan informasi secara terperinci dan disusundalam sebuh latar ilmiah (Hidayah, 2018). selanjutnya Pendekatan ini diambil karena dalam penelitian ini membahas mengenai fenomena yang ada disekitar dan berlangsung secara alamiah.Nama lain dari metode kualitatif yakni penelitian naturalistic, karena pada saat penelitian kondisi yang dialami (natural setting) sesuai dengan apa yang ada disekitarnya (Sugiono, 2017).

Berdasarkan definisi diatas dapat diambil suatu kesimpulan bahwa jenis Penelitian kualitatif merupakan suatu strategi inquiry yang menekankan pencarian makna pengertian, konsep, maupun deskripsi tentang suatu fenomena. Dalam hal ini peneliti hanya bertindak sebagai partisipan yang pasif, maksudnya yakni datang kelokasi penelitian, melihat memerhatikan, mewawancara, serta tidak terlibat secara utuh pada saat penelitian.

\section{PEMBAHASAN}

Penelitian ini dilakukan di SDN 01 Trimodadi Lampung Utara,dengan subjek penelitian peserta didik pada kelas $\mathrm{V}$ dengan jumlah peserta didik sebanyak 19 orang. Dalam mendapatkan data penelitian peneliti membagikan angket dikelas tersebut untuk mengetahui berbagi tipe kepribadian yang dimiliki oleh setiap peserta didik. Hasil penggolongan tipe kepribadian pada 19 anak orang dapat dilihat di table berikut:

Tabel 1. Penggolongan Tipe Kepribadian

\begin{tabular}{|l|l|l|}
\hline NO & Tipe Kepribadian & Jumlah \\
\hline
\end{tabular}


ADI WIDYA: Jurnal Pendidikan Dasar FAKULTAS DHARMA ACARYA UNIVERSITAS HINDU NEGERI

I GUSTI BAGUS SUGRIWADENPASAR
Volume. 6, Nomor 1 April 2021

ISSN: 2685-8312 (online)

ISSN: 2527-5445 (cetak

http://ejournal.ihdn.ac.id/index.php/AW

\begin{tabular}{|c|c|c|}
\hline 1 & Sanguinis & 5 \\
\hline 2 & Plegmatis & 2 \\
\hline 3 & Melankolis & 9 \\
\hline 4 & Koleris & 3 \\
\hline
\end{tabular}

Berdasarkan penggolongan tipe kepribadian diatas diperoleh 5 peserta didik dengan tipe kepribadian sanguinis, 2 peserta didik dengan tipe kepribadian Plegmatis, 9 peserta didik dengan tipe kepribadian melankolis, 3 peserta didik dengan tipe kepribadian koleris. Selanjutnya 61 akan dipilih 4 peserta didik sebagai subjek penelitian dengan masing-masing tipe kepribadian dengan cara purposive sampling yang didasarkan pada hasil wawancara guru kelas V dengan cara melihat hasil ulangan harian untuk menentukan kemampuan matematikanya. Peserta didik yang telah dipilih sebanyak 4 peserta didik dengan tipe kepribadian yang berbeda, yang selanjutnya akan dilakukan tes terhadap soal pemecahan masalah matematika dengan materi FPB dan KPK. Tes dilakukan 2 tahap dengan waktu yang berbeda, waktu penelitian dilakukan dengan persetujuan antara subjek penelitian, peneliti dan pendidik. Penelitian dilakukan dengan tes dan wawancara yang akan direkam dengan menggunakan tape recorder di handphone.

Proses Pemecahan Masalah Dengan Tipe Kepribadian Kolerik Pada Tahap I subjek MH

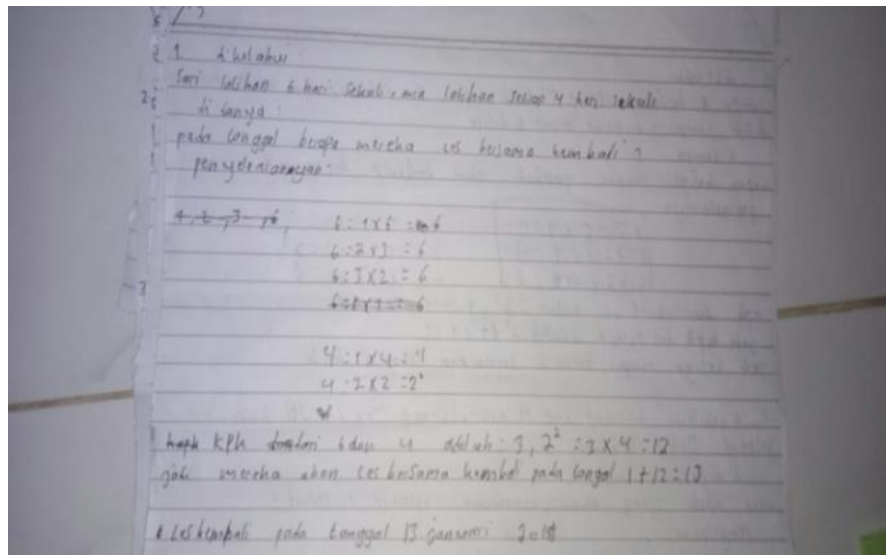

Gambar 1:Lembar Kerja Subjek Tahap 1 


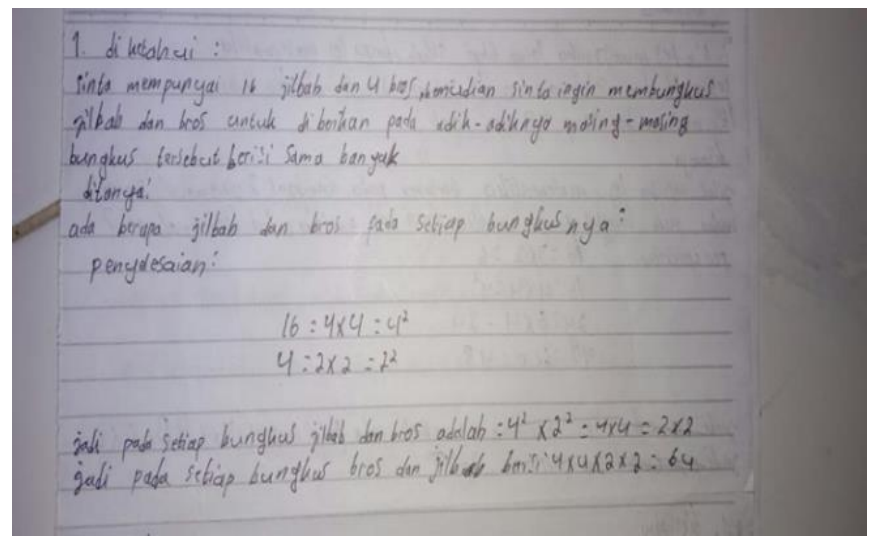

\section{Gambar 2: Lembar kerja Subjek Pada Tahap II}

\section{Triangulasi Data Tahap Proses Pemecahan Masalah Materi FPB dan KPK Dengan Tipe Kepribadian Kolerik Pada Tahap I dan II}

Triangulasi waktu ini berupa perbandingan data pada tes tahap I dan tes tahap II dari subjek MH sehingga diperoleh data untuk mengetahui proses pemecahan masalah yang telah dicapai berdasarkan Teori Polya.

Peneliti melakukan triangulasi hasil penelitian ini, yaiu dengan mencari kesesuian dari satu sumber pada dua kali tahap yaitu tahap I dan taap II dengan tipe kepribadian kolerik dengan inisial MH. Triangulasi ini utuk menguji keabsahan data tahap proses pemecahan masalah peserta didik. Triangulasi yang dimaksud sebagaimana tabel berikut:

Tabel 2. Triangulasi data tahap proses pemecahan masalah pada materi FPB dan KPK dengan tipe kepribadian kolerik inisial MH.

\begin{tabular}{|l|l|l|}
\hline $\begin{array}{c}\text { Langkah- } \\
\text { langkah } \\
\text { penyelesaian } \\
\text { masalah }\end{array}$ & \multicolumn{1}{|c|}{$\begin{array}{c}\text { Proses Pemecahan Masalah } \\
\text { Tahap I }\end{array}$} & \multicolumn{1}{|c|}{$\begin{array}{c}\text { Proses Pemecahan Masalah } \\
\text { Tahap II }\end{array}$} \\
\hline Memahami & $\begin{array}{l}\text { Mampu menuliskan apa yang } \\
\text { diketahui dan ditanyakan dari } \\
\text { masalah yang diajukan. }\end{array}$ & $\begin{array}{l}\text { Mampu menuliskan pa yang } \\
\text { diketahui dan ditanyakan dari } \\
\text { masalah yang diajukan. }\end{array}$ \\
\hline Merencanakan & $\begin{array}{l}\text { Menceritakan/menuliskan } \\
\text { lagkah-langkah untuk } \\
\text { menyelesaikan masalah. }\end{array}$ & $\begin{array}{l}\text { Menceritakan/menuliskan langkah- } \\
\text { langah menyelesaikan } \\
\text { masalah. }\end{array}$ \\
\hline $\begin{array}{l}\text { Melaksantuk } \\
\text { Rencana }\end{array}$ & $\begin{array}{l}\text { Melaksanakan rencana yang } \\
\text { telah dibuat, menggunakan } \\
\text { langkah-langkah menyelesaikan } \\
\text { masalah tetapi terjadi kesalahan } \\
\text { procedural dan perhitungan. }\end{array}$ & $\begin{array}{l}\text { Melaksanakan rencana yang telah } \\
\text { dibuat, menggunakan langkah- } \\
\text { langkah menyelesaikan masalah } \\
\text { mangan }\end{array}$ \\
\hline
\end{tabular}


ADI WIDYA: Jurnal Pendidikan Dasar FAKULTAS DHARMA ACARYA UNIVERSITAS HINDU NEGERI
Volume. 6, Nomor 1 April 2021

ISSN: 2685-8312 (online)

ISSN: 2527-5445 (cetak

http://ejournal.ihdn.ac.id/index.php/AW

\begin{tabular}{|l|l|l|}
\hline & & $\begin{array}{l}\text { dengan benar, tidak terjadi kesalahan } \\
\text { procedural dan perhitungan. }\end{array}$ \\
\hline $\begin{array}{l}\text { Memeriksa } \\
\text { kembali }\end{array}$ & $\begin{array}{l}\text { Tidak melakukan pemeriksaan } \\
\text { kembali jawaban. }\end{array}$ & $\begin{array}{l}\text { Melakukan pemeriksaan kembali } \\
\text { jawaban. }\end{array}$ \\
\hline
\end{tabular}

Jadi berdasarkan penjelasan tabel diatas maka disimpulkan bahwa subjek dengan tipe kepribadian kolerik pada tahap I sudah memenuhi keempat tahap pemecahan masalah berdasarkan teori polya, selanjutnya pada tahap II sudah memenuhi keempat tahap pemecahan masalah berdasarkan teori Polya.

Proses Pemecahan Masalah Dengan Tipe Kepribadian Melankolik Pada Tahap I subjek ARA

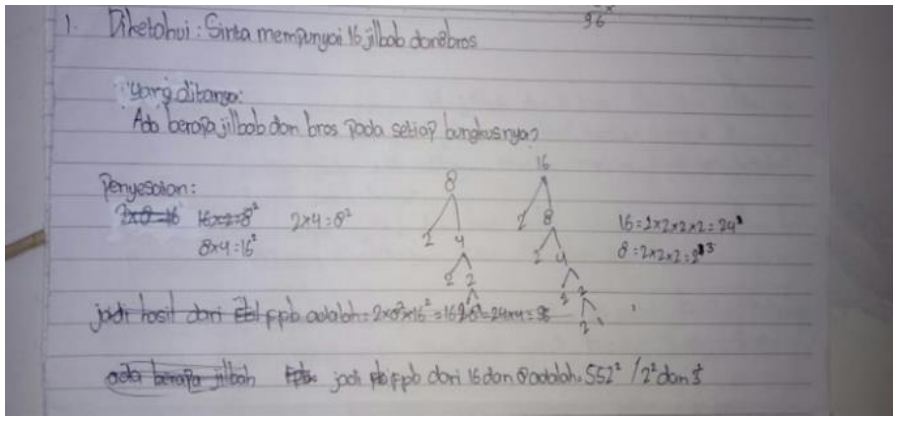

Gambar 3. Lembar Kerja Subjek Tahap I

Proses Pemecahan Masalah Dengan Tipe Kepribadian Melankolik Pada Tahap II subjek ARA

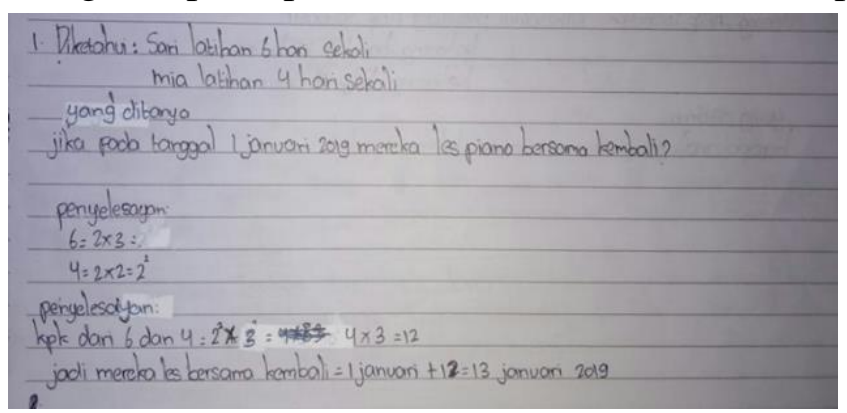

Gambar 4. Lembar kerja Subjek Tahap II

Triangulasi Data Tahap Proses Pemecahan Masalah materi FPB dan KPK Tipe Kepribadian Melankolik Pada Tahap I dan II

Triangulasi waktu ini berupa perbandingan data pada tes tahap I dan tes tahap II dari subjek ARA sehingga diperoleh data untuk mengetahui proses pemecahan masalah yang telah dicapai berdasarkan Teori Polya.

Peneliti melakukan triangulasi hasil penelitian ini, yaiu dengan mencari kesesuian dari satu sumber pada dua kali tahap yaitu tahap I dan taap II dengan tipe kepribadiak melankolik 
dengan inisial ARA. Triangulasi ini utuk menguji keabsahan data tahap proses pemecahan masalah peserta didik. Triangulasi yang dimaksud sebagaimana tabel berikut:

Tabel 3. Triangulasi Data Tahap Pemecahan Masalah Matematika Materi FPB dan KPK Tipe Kepribadian Melankolik Inisial ARA

\begin{tabular}{|l|l|l|}
\hline $\begin{array}{c}\text { Langkah-langkah } \\
\text { penyelesaian } \\
\text { masalah }\end{array}$ & $\begin{array}{c}\text { Proses Pemecahan } \\
\text { Masalah } \\
\text { Tahap I }\end{array}$ & Proses Pemecahan Masalah Tahap II \\
\hline Memahami & $\begin{array}{l}\text { Mampu menuliskan apa } \\
\text { yang diketahui dan } \\
\text { ditanyakan dari masalah } \\
\text { terebut }\end{array}$ & $\begin{array}{l}\text { Mampu menuliskan apa yang diketahui dan } \\
\text { ditanyakan dari masalah terebut }\end{array}$ \\
\hline Merencanakan & $\begin{array}{l}\text { Mampu menuliskan } \\
\text { langkah-langkah untuk } \\
\text { menyelesaikan masalah }\end{array}$ & $\begin{array}{l}\text { Mampu menuliskan langkah-langkah untuk } \\
\text { menyelesaikan masalah }\end{array}$ \\
\hline $\begin{array}{l}\text { Melaksanakan } \\
\text { rencana }\end{array}$ & $\begin{array}{l}\text { Melaksanakan rencana } \\
\text { yang telah dibuat, tetapi } \\
\text { terjadi kesalahan } \\
\text { procedural dan } \\
\text { perhitungan }\end{array}$ & $\begin{array}{l}\text { Melaksanakan rencana sesuai procedural } \\
\text { dan tidak terjadi kesalahan perhitungan }\end{array}$ \\
\hline Memeriksa kembali & $\begin{array}{l}\text { Tidak melakukan } \\
\text { pemeriksaan kembali } \\
\text { atas jawaban akhir }\end{array}$ & Melakukan pemeriksaan kembali \\
\hline
\end{tabular}

Jadi berdasarkan penjelasan tabel diatas maka disimpulkan bahwa subjek dengan tipe kepribadian kolerik pada tahap I sudah memenuhi keempat teori pemecahan masalah berdasarkan Teori Polya, sedangkan pada tahap II sudah memenuhi keempat tahap pemecahan masalah berdasarkan Teori Polya.

Proses Pemecahan Masalah Dengan Tipe Kepribadian Sanguinis Pada Tahap I subjek AGA

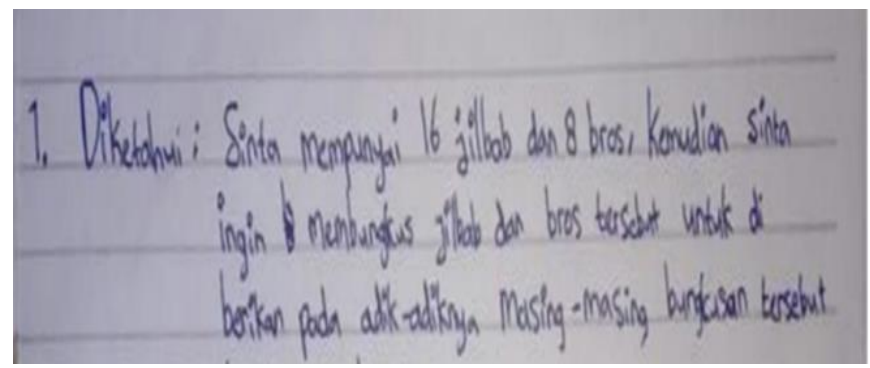

Gambar 5. Kerja Subjek Tahap I

Proses Pemecahan Masalah Dengan Tipe Kepribadian Sanguinis Pada Tahap II subjek AGA

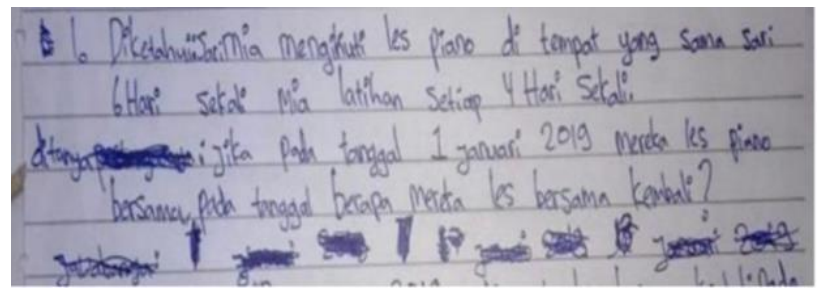


ADI WIDYA: Jurnal Pendidikan Dasar FAKULTAS DHARMA ACARYA UNIVERSITAS HINDU NEGERI
Volume. 6, Nomor 1 April 2021

ISSN: 2685-8312 (online)

ISSN: 2527-5445 (cetak

http://ejournal.ihdn.ac.id/index.php/AW

\section{Gambar 6. Lembar Kerja Subjek Tahap II}

Triangulasi Data Tahap Proses Pemecahan Masalah Materi FPB dan KPK Dengan Tipe Kepribadian Sanguinis Pada Tahap I dan II

Triangulasi waktu ini berupa perbandingan data pada tes tahap I dan tes tahap II dari subjek AGA sehingga diperoleh data untuk mengetahui proses pemecahan masalah yang telah dicapai berdasarkan teori polya.

Peneliti melakukan triangulasi hasil penelitian ini, yaiu dengan mencari kesesuian dari satu sumber pada dua kali tahap yaitu tahap I dan taap II dengan tipe kepribadiak melankolik dengan inisial AGA. Triangulasi ini utuk menguji keabsahan data tahap proses pemecahan masalah peserta didik. Triangulasi yang dimaksud sebagaimana table berikut:

Tabel 4. Triangulasi Data Tahap Pemecahan Masalah Matematika Materi FPB dan KPK Tipe Kepribadian Sanguinis inisial AGA

\begin{tabular}{|l|l|l|}
\hline \multicolumn{1}{|c|}{$\begin{array}{c}\text { Langkah-langkah } \\
\text { penyelesaian masalah }\end{array}$} & \multicolumn{1}{|c|}{$\begin{array}{c}\text { Proses Pemecahan } \\
\text { Masalah } \\
\text { Tahap I }\end{array}$} & $\begin{array}{l}\text { Proses Pemecahan } \\
\text { Masalah Tahap II }\end{array}$ \\
\hline Memahami & $\begin{array}{l}\text { Mampu meuliskan apa } \\
\text { yang diketahui dan ditanyakan }\end{array}$ & $\begin{array}{l}\text { Mampu menuliskan apa } \\
\text { yang diketahui dan } \\
\text { ditanyakan }\end{array}$ \\
\hline Merencanakan & $\begin{array}{l}\text { Tidak menuliskan langah-langkah } \\
\text { untuk menyelesaikan masalah. }\end{array}$ & $\begin{array}{l}\text { Tidak menuliskan langah- } \\
\text { langkah untuk } \\
\text { menyelesaikan masalah. }\end{array}$ \\
\hline Melaksanakan & $\begin{array}{l}\text { Tidak mampu melaksanakan } \\
\text { rencana karena masih terdapat } \\
\text { beberap hambatan ditahap } \\
\text { sebelumnya }\end{array}$ & $\begin{array}{l}\text { Tidak mampu } \\
\text { melaksanakan rencana } \\
\text { karena masih terdapat } \\
\text { beberap hambatan ditahap } \\
\text { sebelumnya }\end{array}$ \\
\hline Memeriksa & $\begin{array}{l}\text { Tidak melakukan pemeriksan } \\
\text { kembali }\end{array}$ & $\begin{array}{l}\text { Tidak melakukan } \\
\text { pemeriksan kembali }\end{array}$ \\
\hline
\end{tabular}

Jadi berdasarkan table diatas disimpulkan bahwa subjek dengan tipe kepribadian sanguinis sudah memnuhi tahapan pemecahan masalah berdasarkan teori polya akan tetapi hanya mampu melalui tahap memahami saja pada tahap I dan tahap II. Subjek AGA hanya menuliskan apa yang diketahui dan ditanyakan saja tidak menuliskan strategi yang digunakan serta melakukan rencana serta tidak melakukan pengecekan jawaban kembali.

Proses Pemecahan Masalah Dengan Tipe Kepribadian Plegmatik Pada Tahap I subjek AA

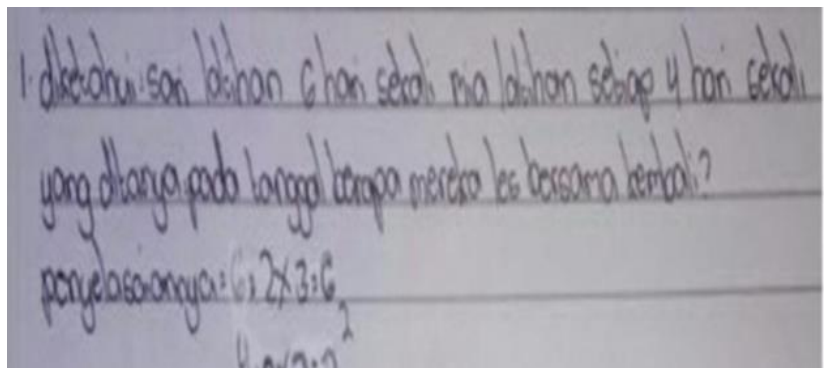




\section{Gambar 7. Lembar Kerja Subjek Tahap I}

Proses Pemecahan Masalah Dengan Tipe Kepribadian Plegmatik Pada Tahap II subjek AA

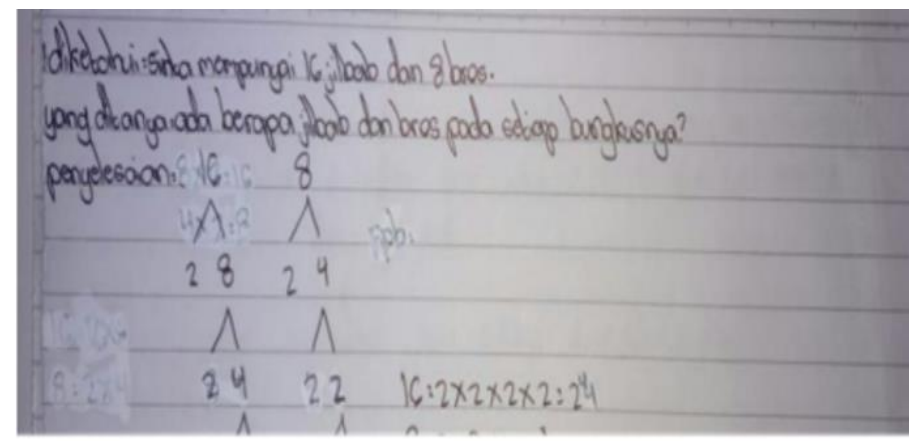

Gambar 8. Lembar Kerja Subjek Tahap II

Triangulasi Data Tahap Pemecahan Masalah Materi FPB dan KPK Dengan Tipe Kepribadian Plegmatik Pada Tahap I dan II

Triangulasi waktu ini berupa perbandingan data pada tes tahap I dan tes tahap II dari subjek AA sehingga diperoleh data untuk mengetahui proses pemecahan masalah yang telah dicapai berdasarkan teori polya. Peneliti melakukan triangulasi hasil penelitian ini, yaiu dengan mencari kesesuian dari satu sumber pada dua kali tahap yaitu tahap I dan taap II dengan tipe kepribadiak plegmatik dengan inisial AA. Triangulasi ini utuk menguji keabsahan data tahap proses pemecahan masalah peserta didik. Triangulasi yang dimaksud sebagaimana table berikut:

Tabel 5. Triangulasi Data Tahap Pemecahan Masalah Matematika Materi FPB dan KPK Tipe Kepribadian Plegmatik inisial AA

\begin{tabular}{|l|l|l|}
\hline $\begin{array}{l}\text { Langkah-langkah } \\
\text { penyelesaian masalah }\end{array}$ & $\begin{array}{l}\text { Proses Pemecahan } \\
\text { Masalah } \\
\text { Tahap I }\end{array}$ & $\begin{array}{l}\text { Proses Pemecahan } \\
\text { Masalah Tahap II }\end{array}$ \\
\hline Memahami & $\begin{array}{l}\text { Mampu menuliskan apa } \\
\text { yang diketahui dan ditanyakan } \\
\text { dari masalah terssebut }\end{array}$ & $\begin{array}{l}\text { Mampu menuliskan apa } \\
\text { yang diketahui dan ditanyakan } \\
\text { dari maalah tersebut }\end{array}$ \\
\hline Merencanakan & $\begin{array}{l}\text { Mampu menuliskan } \\
\text { langkah-langkah untuk } \\
\text { menyelesaikan masalah }\end{array}$ & $\begin{array}{l}\text { Mampu menuliskan } \\
\text { langkah-langkah untuk } \\
\text { menyelesaikan masalah }\end{array}$ \\
\hline Melaksanakan Rencana & $\begin{array}{l}\text { Melaksanakan rencana } \\
\text { yang telah dibuat, tetapi terjadi } \\
\text { kesalahan procedural dan } \\
\text { perhitungan }\end{array}$ & $\begin{array}{l}\text { Melaksanakan rencana } \\
\text { sesuai procedural dan tidak } \\
\text { terjadi kesalahan perhitungan }\end{array}$ \\
\hline
\end{tabular}


ADI WIDYA: Jurnal Pendidikan Dasar FAKULTAS DHARMA ACARYA UNIVERSITAS HINDU NEGERI

I GUSTI BAGUS SUGRIWADENPASAR
Volume. 6, Nomor 1 April 2021

ISSN: 2685-8312 (online)

ISSN: 2527-5445 (cetak

http://ejournal.ihdn.ac.id/index.php/AW

\begin{tabular}{|l|l|l|}
\hline Memeriksa Kembali & $\begin{array}{l}\text { Tidak melakukan pemeriksaan } \\
\text { kembali atas jawaban akhir }\end{array}$ & $\begin{array}{l}\text { Melakukan } \\
\text { pemeriksaan kembali }\end{array}$ \\
\hline
\end{tabular}

Berdasarkan table diatas bahwa subjek AA pada tahap I sudah memenuhi keempat tahap pemecahan masalah berdasarkan teori polya meski masih terdapat kesalahan pada tahap melaksanakan rencana, sedangkan pada tahap II subjek AA sudah memenuhi keempat tahap pemecahan masalah berdasarkan Teori Polya.

\section{SIMPULAN}

Berdasarkan hasil penelitian dan pembahasan yang telah diuraikan, maka disimpulkan bahwa analisis proses pemecahan masalah matematika pada materi FPB dan KPK dengan tipe kepribadian Kolerik, Melankolik, Sanguinis, Plegmatik adalah sebagai berikut:

1. Proses Pemecahan Masalah Peserta Didik Tipe Kepribadian Kolerik

Tipe kolerik mampu menuliskan apa yang diketahui dan apa yang ditayakan dalam soal tersebut. Dalam memecahkan masalah subjek mampu menuliskan motode yan digunakan dalam menyelesaikan soal tersebut. Selanjutnya subjek mampu menuliskan langkah mengerjakan soal tersebut. Mampu memeriksa kembali jawaban akan tetapi di tahap I tidak melakukan pemeriksaan kembali karena terjadi kesalahan pada tahap melaksanakan rencana.

\section{Proses Pemecahan Masalah Peserta Didik Tipe Kepribadian Melankolik}

Berdasarkan hasil deskripsi dan hasil analisis di atas dapat disimpulkan bahwa proses pemecahan masalah matematika dengan tipe kepribadian plegmatik dalam menyelesaikan soal FPB dan KPK. Subjek mampu menulis dan menjelaskan apa yang diketahui dan apa yang ditanyakan dalam soal tersebut. Subjek juga mampu dalam memecahkan masalah dari soal dengan mengubah apa yang diketahui dari soal kedalam bentuk matematika serta mampu mampu menentukan metode penyelesaiannya. Subjek juga mampu menuliskan dan menjelaskan langkah-langkah yang ditempuh dalam menyelesaikan soal dengan menggunakan konsep yang sudah dipelajari serta dapat menyimpulkan jawaban yang telah didapat, meski masih terjadi beberapa kesalahan dalam hal perhitungan.

3. Proses Pemecahan Masalah Peserta Didik Tipe Kepribadian Sanguinis

Tipe sanguinis kurang mampu dalam menghubungkan informasi yang diperolehnya. Dalalam memecahkan masalah subjek mampu dalam menuliskan apa yang diketahui serta apa yang ditanyakan dalam soal tersebut akan tetapi subjek kurang mampu dalam menentukan langkah-langkah penyelesaiannya serta dalam menjawab persoalan tipe sanginis kurang menggunakan konsep yang sudah dipelajari. Selanjutnya dalam menyimpulkan jawaban subjek tidak dapat menyimpulkan karena subjek tidak menyelesaikan jawaban hingga akhir.

4. Proses Pemecahan Masalah Peserta Didik Tipe Kepribadian Plegmatik 
Tipe Plegmatis ini mampu menuliskan apa yang diketahui dan ditanyakan dalam soal tersebut. selanjutnya subjek mampu menuliskan rencana penyelesaian masalahnya melaksanakan penyelesaian masalah, serta melakukan evaluasi.

\section{DAFTAR PUSTAKA}

Ahmadi, Abu, and Widodo Supriyono. 2013. Psikologi Belajar. Jakarta: Rineka Cipta.

Amalia, Sofri Rizka. 2018. "Analisis Kemampuan Pemecahan Masalah Mahasiswa Melalui Model PBL Berbasis Etnomatematika Ditinjau Dari Kepribadian Topologi

Hippocrates, Galenus Tipe Choleris Dan Phlegmatis.” Jurnal Aksioma 9 (1): 1-10.

Anwar, Chairul. 2017. Teori-Teori Pendidikan. Yogyakarta: IRCiSoD.

Barnawi, and M. Arifin. 2017. Micro Teaching. Yogyakarta: Ar-Ruzz Media.

Dewi, Sri, Rayandra Asyar, and Kamid. 2013. "Analisis Pemecahan Masalah Matematika Pada

Siswa Tipe Visual Berbasis Realistic Mathematics Education ( RME) Di Kelas VIII SMP N 2 Kota Jambi.” Jurnal Tekno-Pedagogi 3 (2): 42-51.

Hasmila, Sari. 2016. "Hubungan Tipe Kepribadian Dengan Motivasi Belajar Pada Fakultas Keperawatan Universitas Syiah Kuala The Correlation Between Personality Type And Motivation To Learn In Student With Competency Based Curriculum.”

Hidayah, Nurul. 2018. "Analisis Kesiapan Mahasiswa Prodi Pendidikan Guru Madrasah Ibtidaiyah Sebagai Calon Pendidik Profesional.” TERAMPIL: Jurnal Pendidikan Dan Pembelajaran Dasar 5 (1): 117-37.

Mawaddah, Siti, and Hana Anisah. 2015. "Kemampuan Pemecahan Masalah Matematis Siswa Pada Pembelajaran Matematika Dengan Menggunakan Model Pembelajaran Generatif (Generative Learning) Di SMP.” Edu-Mat Jurnal Pendidikan Matematika 3 (2): 15575.

Negara, Hasan Sastra. 2016. Konsep Dasar Matematika Untuk PGSD. Bandar Lampung: AURA.

Saputri, Hanifah Ayu. 2018. Pengaruh Tipe Kepribadian Dosen Terhadap Motivasi Berprestasi Mahasiswa. Surakarta: Universitas Muhammadiyah Surakarta.

Sjarkawi. 2011. Pembentukan Kepribadian Anak: Peran Moral, Intelektual, Emosional, Dan Sosial Sebagai Wujud Integrasi Jati Diri. Jakarta: Bumi Aksara.

Sugiono. 2013. Metode Penelitian Pendidikan Pendekatan Kualitatif, Kuantitadif, Dan R\&D. Bandung: Alfabeta.

Ulfah, Jannah, and Aninditya Sri Nugraheni. 2020. "Design Development Of Indonesian Teaching Materials In Health Insights In Elementary School In The Pandemic Covid19." Primary: Jurnal Pendidikan Guru Sekolah Dasar 9 (4): 548.

Yunianto, Teguh and Rokhimawan Agung. 2021. "Analisis Kesesuaian Materi IPA Dalam Buku Siswa Kelas IV Semester 1 SD/MI Dengan Kurikulum 2013.”EduHumaniora 13 (1): 43-51.

Yunianto, Teguh, Hasan Sastra Negara, and Suherman. 2019. "Flip Builder: Pengembangannya Pada Media Pembelajaran Matematika." TERAMPIL: Jurnal Pendidikan Dan Pembelajaran Dasar 6 (2): 115-27.

Yunianto, Teguh, Suyadi, and Suherman. 2020. "Pembelajaran Abad 21: Pengaruhnya Terhadap Pembentukan Karakter Akhlak Melalui Pembelajaran STAD Dan PBL Dalam Kurikulum 2013." Premiere Educandum 10 (2): 203- 